\title{
PENGARUH VARIABEL FUNDAMENTAL TERHADAP HARGA SAHAM
}

\author{
Aditya Rusli \\ Sekolah Tinggi Ilmu Ekonomi Indonesia Malang
}

\begin{abstract}
Stock Exchange truly is a set of arrangement which enables long-term claim exchange, enables addition of financial assets (and debt) and at the same time, enables investor to always change and adjust his investment portfolio (through secondary market). For people in general, the existence of Stock Exchange can be an alternative choice of In this study, researcher used firm internal fundamental variables to test the relation of some fundamental variables on the price of stock. Internal fundamental variables like Price Earning Ratio, Price Book Price, Debt to Equity Ratio, Total Asset Turnover, Return on Investment, Return on Equity, Net Profit Margin, and Operating Profit Margin can be used as fundamental analysis variables that affect changes on stock price. Analysis model used was double regression model using 10 emitted mining companies' stocks.

The results of the study showed the existence of effect either all together or partially on fundamental variable against changes of stock price on go public mining companies in Jakarta Stock exchange (JSC). Of eight variables proposed; Price Earning Ratio, Return on Investment, Return on Equity, and Operating Profit Margin variables are variables that might affect stock price. Independent variables that affect stock price is Operating Profit Margin variables which means that mining sector can be a very prospective sector in the future if it is supported with good performance and good activities as well.
\end{abstract}

Key words: investment analysis, fundamental variable, stock price.

Pasar Modal pada hakikatnya adalah jaringan tatanan yang memungkinkan pertukaran klaim jangka panjang, memungkinkan penambahan financial assets (dan hutang) pada saat yang sama memungkinkan investor untuk selalu merubah dan menyesuaikan portofolio investasinya (melalui pasar sekunder). Kegiatan pasar modal di Indonesia dimulai pada tahun 1977. Sewaktu pasar modal diaktifkan, ada beberapa tujuan yang ingin dicapai. Pertama, untuk memobilisasi dana diluar sistem perbankan. Kedua, untuk memperluas distribusi kepemilikian saham-saham terutama ke pemodal-pemodal kecil. Dan ketiga untuk memperluas dan memperdalam sektor keuangan. 
Bagi masyarakat, kehadiran pasar modal merupakan tambahan alternatif investasi yang selama ini dirasakan masih terbatas di Indonesia. Akibat dari banyaknya pilihan investasi yang ditawarkan, tentunya investor perlu pertimbangan-pertimbangan seperti informasi keuangan, perhitunganperhitungan dan analisis yang memadai serta perlu mengetahui keadaan dan prospek perusahaan yang menjual sahamnya di pasar modal.

Walaupun terdapat peluang munculnya suatu risiko, namun pasar modal dan transaksi perdagangan saham tetap menjadi pilihan yang menarik untuk investasi, khususnya di pasar sekunder, menginngat ada keuntungankeuntungan yang bisa diperoleh bagi investor, yaitu:

1. Bunga atau dividend yield yang akan dibagikan pada pemegang saham bila perusahaan memperoleh laba perusahaan.

2. Capital gain atau apresiasi atas harga saham yang merupakan selisih harga pembelian saham dan penjualan saham.

3. Investasi bersifat likuid artinya mudah dijual atau diuangkan kembali.

4. Sebagai alternatif pilihan dalam melakukan investasi.

5. Perpindahan kepemilikan dari satu saham ke saham lain (yang dianggap lebih menguntungkan) mudah dilakukan.

6. Memperoleh hak suara dalam menentukan jalannya perusahaan.

Di dalam Pasar Modal, keuntungan dari saham dapat dikaitkan dengan harga saham yang disebut kurs. Nilai kurs ini tergantung dari kinerja dan prospek perusahaan yang mengeluarkan saham tersebut. Menurut Subroto (1991) investasi atau penanaman modal dalam saham adalah pemilikan atau pembelian saham-saham perusahaan lain oleh suatu perusahaan dengan tujuan untuk memperoleh pendapatan (income) atau tambahan di luar pendapatan dari usaha pokoknya.

Mengetahui kinerja keuangan suatu perusahaan merupakan suatu hal yang penting terutama bagi pihak-pihak yang berkepentingan dan ada kaitannya dengan kelangsungan hidup perusahaan, misalnya investor, calon investor, manajer, kreditur, pemerintah, dan masyarakat yang ingin memperoleh informasi mengenai perkembangan perusahaan terutama yang berkaitan dengan kinerja keuangan. Bagi pihak menejemen terutama sangat berguna untuk 
melakukan perbaikan-perbaikan serta menyusun strategi perusahaan dimasa yang akan datang.

Banyak peneliti yang menyatakan bahwa variabel Fundamental dan faktor teknikal memiliki pengaruh terhadap perubahan harga saham. Faff dan Hiller (2000), menggunakan variabel fundamental yaitu: Price Earning Ratio, Price Book Value, Debt to Equity Ratio, Total Asset Turn Over, Return on Investment, Return on Equity, Net Profit Margin, Operating Profit Margin untuk menganalisa perubahan harga saham. Analisis harga saham dengan menggunakan variabel fundamental juga dilakukan oleh Leki (1997). Sedangkan D. Silalahi (1991), menggunakan variabel teknikal berupa volume perdagangan saham untuk menganalisa perubahan harga saham. Dalam hal ini, kita menggunakan variabel Fundamental sebagai alat untuk menganalisa perubahan harga saham. Variabel Fundamental yang digunakan peneliti terdiri dari: Price Earning Ratio, Price Book Value, Debt to Equity Ratio, Total Asset Turn Over, Return on Investment, Return on Equity, Net Profit Margin, Operating Profit Margin.

Disini kita hanya menggunakan variabel Fundamental internal perusahaan untuk mengetahui dan menguji keterkaitan beberapa variabel fundamental yang terdiri dari: Price Earning Ratio, Price Book Value, Debt to Equity Ratio, Total Asset Turn Over, Return on Investment, Return on Equity, Net Profit Margin, Operating Profit Margin, secara bersama-sama (serentak) maupun sendirisendiri (partial) berpengaruh terhadap harga saham pada perusahaan pertambangan yang go public di Bursa Efek Indonesia (BEI). Selain itu penulis ingin mengetahui variable mana yang paling dominan pengaruhnya terhadap harga saham.

\section{Kerangka Konseptual Penelitian}

Penelitian ini membangun kerangka konseptual dengan mendasarkan pada keterkaitan variabel secara teoritis, kajian penelitian-penelitian sebelumnya dan secara spesifik adalah mempertimbangkan variabel-variabel yang telah terspesifikasi dalam rumusan permasalahan maupun tujuan dari penelitian.

Berkaitan dengan penelitian ini analisis fundamental yang dipergunakan untuk mengukur kinerja perusahaan diindikasikan dengan 8 (delapan) konsep yaitu: PER, PBV, DER, TATO, ROI, ROE, NPM, dan operating profit margin. 


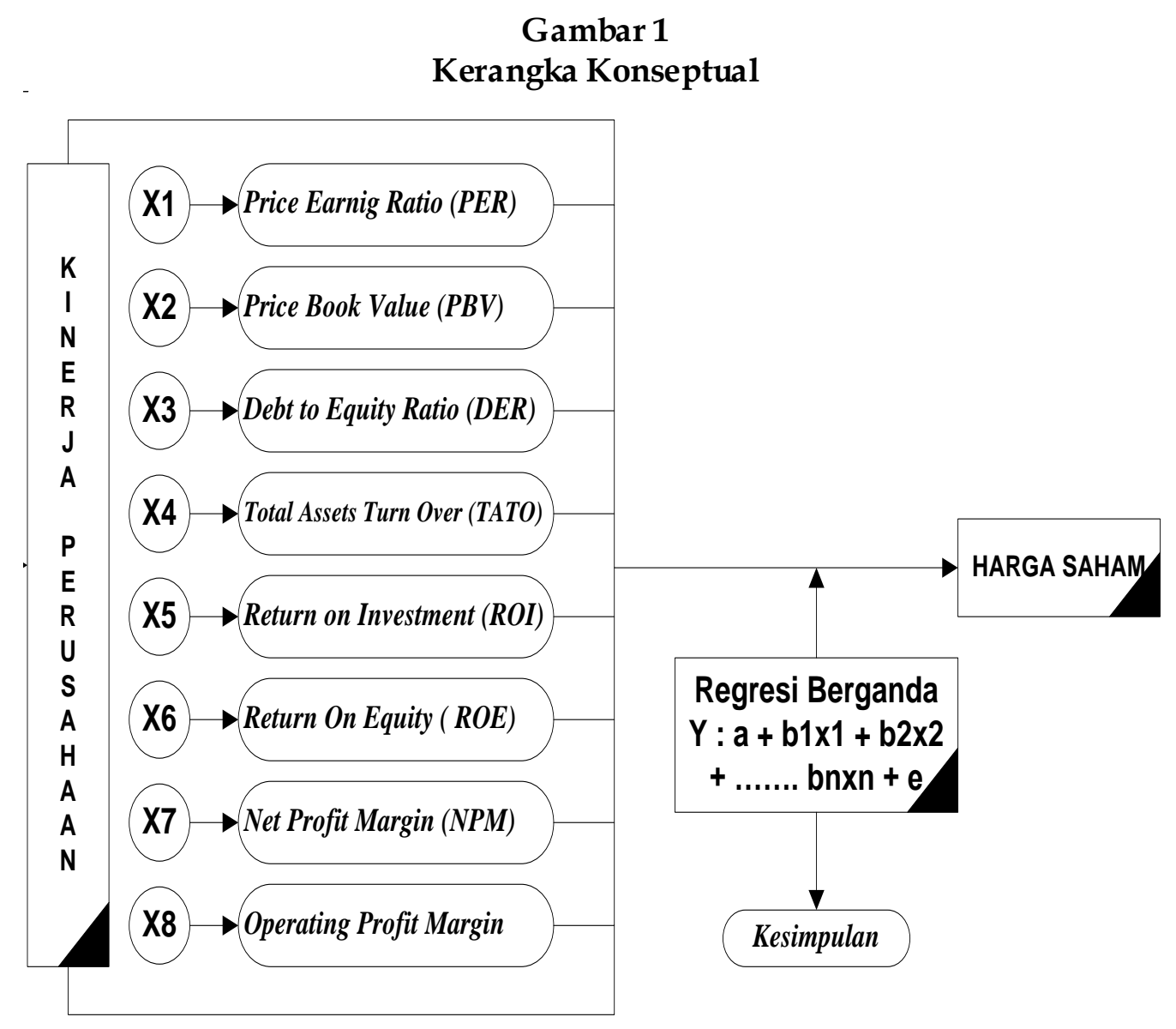

\section{Hipotesis}

Dengan mengacu pada rumusan masalah, tinjauan teoritis serta beberapa penelitian terdahulu yang diuraikan sebelumnya, maka hipotesis yang diajukan dalam penelitian ini adalah:

1. Diduga variabel fundamental seperti: Price Earning Ratio, Price Book Value, Debt to Equity Ratio, Total Asset Turn Over, Return on Investment, Return on Equity, Net Profit Margin, Operating Profit Margin baik secara serentak (simultan) maupun parsial (partial) memiliki pengaruh dan signifikan terhadap harga saham pada perusahaan pertambangan yang go public di Bursa Efek Indonesia (BEI).

2. Diduga diantara variabel fundamental, variabel Price Earning Ratio (PER) mempunyai pengaruh yang dominan terhadap harga saham pada perusahaan pertambangan yang go public di Bursa Efek Indonesia (BEI). 


\section{METODE}

Jenis penelitian ini dapat dikatakan sebagai Explanatory Reseach dengan prosedur pengujian hipotesis (hypothesis testing) untuk menjawab pertanyaan dan tujuan penelitian. Penelitian akan dilakukan pada Bursa Efek Indonesia dan beberapa tempat yang telah ditunjuk BEI dimana dapat diperoleh informasi yang relevan.

Berdasarkan model analisis data, penelitian ini dikategorikan dalam penelitian analitis. Penelitian analitis dilakukan untuk menganalisis unit data yang muncul dari fenomena, dalam hal ini pengambilan sampel untuk digeneralisasi dalam populasi. Dalam penelitian analitis model pendekatan yang dilakukan adalah pengujian hipotesis (hypothetical testing). Serangkaian hipotesis yang diajukan dalam penelitian dianalisis untuk membuktikan kebenaran dari hipotesis tersebut.

\section{Populasi}

Populasi dalam penelitian ini perusahaan yang termasuk dalam 10 (sepuluh) perusahaan pertambangan yang go publik di Bursa Efek Indonesia mulai tahun 2003 sampai tahun 2007 dan telah memberikan laporan keuangan. Perusahaan pertambangan tersebut antara lain:

Tabel 1

Populasi Perusahaan Pertambangan

\begin{tabular}{|c|l|l|}
\hline No. & \multicolumn{1}{|c|}{ Nama Perusahaan } & \multicolumn{1}{|c|}{ Penjamin Emisi } \\
\hline 1. & Alter Abadi Tbk & Makindo \\
\hline 2. & Aneka Tambang (Persero) Tbk & Danareksa Sekuritas \\
\hline 3. & Apexindo Pratama Duta Tbk & Bahana Securities \\
\hline 4. & Bumi Resourcer. Tbk & Bakrie Securities \\
\hline 5. & Citatah Industri Marmer Tbk & Lippo Securities \\
\hline 6. & Central Korporindo Internasional Tbk & Asjaya Indosurya Securities \\
\hline 7. & International Nickel Indonesia (INCO) Tbk & Danareksa Sekuritas \\
\hline 8. & Medco Energi International Tbk & Sinartama Gunita \\
\hline 9. & Tambang Batubara Bukit Asam Tbk & Danareksa Sekuritas \\
\hline 10. & Tambang Timah Tbk & Niaga Sekuritas \\
\hline
\end{tabular}

Jumlah sampel yang diambil adalah semua perusahaan pertambangan dengan kriteria bahwa telah memenuhi persyaratan atas dasar ketersediaan data selama 5 tahun/minimal go public selama 5 tahun sesuai dengan periode penelitian yang diperlukan yaitu dari tahun 2003 sampai dengan tahun 2007. 


\section{Sampel}

Penarikan sampel perusahaan dilakukan dengan menggunakan metode sensus. Sensus adalah penelitian dengan mendaftarkan seluruh populasi atau kelompok pada waktu tertentu, dengan titik berat pencatatan/pencacahan ciri tertentu dari populasi tersebut. Dalam hal ini keseluruhan perusahaan sektor pertambangan yang go public di Bursa Efek Indonesia digunakan sebagai objek penelitian.

\section{Variabel Penelitian}

Variabel yang diuji dalam penelitian ini adalah harga saham pada saat penutupan (closing price) dari setiap perusahaan sebagai variabel dependen serta sinyal fundamental sebagai variabel independen.

\section{Data dan Sumber data}

Sumber data yang digunakan dalam penelitian ini adalah data sekunder, baik yang berasal dari dalam perusahaan (sumber data internal) maupun data dari luar perusahaan (sumber data eksternal).

\section{Teknik Analisis Data - Model Analisis}

Untuk menyatakan kejelasan tentang kekuatan beberapa variabel penentu terhadap harga saham digunakan model regresi linier berganda dengan metode kuadrat terkecil. Model analisis statistik ini dipilih karena penelitian ini dirancang untuk mengetahui variabel-variabel yang berpengaruh dari variabel bebas terhadap variabel terikat, yang didasarkan pada pooling data (time series dan cross sectional). Persamaan umum dari model tersebut adalah (Gujarati 1995) sebagai berikut:

$$
Y=a+\beta_{1} X_{1}+\beta_{2} X_{2}+\beta_{3} X_{3}+\beta_{4} X_{4}+\beta_{5} X_{5}+\beta_{6} X_{6}+\beta_{7} X_{7}+\beta_{8} X_{8}+e
$$

dimana:

$\begin{array}{ll}\mathrm{Y}_{1} & =\text { Harga Saham Penutupan (Closing Price) } \\ \mathrm{X}_{1} & =\text { Price Earning Ratio. } \\ \mathrm{X}_{2} & =\text { Price Book Value. } \\ \mathrm{X}_{3} & =\text { Debt to Equity Ratio. } \\ \mathrm{X}_{4} & =\text { Total Asset Turn Over. } \\ \mathrm{X}_{5} & =\text { Return on Invtment. } \\ \mathrm{X}_{6} & =\text { Return on Equity. } \\ \mathrm{X}_{7} & =\text { Net Profit Margin. } \\ \mathrm{X}_{8} & =\text { Operating Profit Margin. }\end{array}$




$$
\begin{array}{ll}
\mathrm{a} & =\text { Konstanta } \\
\beta_{1} \ldots . . \beta_{6} & =\text { Koefisisen regresi } \\
\mathrm{e}_{\mathrm{i}} & =\text { Kesalahan pengganggu }
\end{array}
$$

\section{Pengujian Hipotesis}

Pengujian hipotesis penelitian ini dilakukan dengan melakukan regresi variabel dependen dengan variabel independen, sehingga didapat koefisien regresi berdasarkan nilai $\mathrm{t}$. Apabila sig t lebih besar dari tingkat alpha yang digunakan, maka variabel independen tidak berpengaruh terhadap variabel dependen, begitu juga sebaliknya. Untuk menentukan tingkat signifikansi secara keseluruhan variabel independen dengan variabel dependen dilakukan dengan menggunakan uji F. Uji ini digunakan untuk mengetahui tingkat signifikansi pengaruh variabel variabel independen secara bersama-sama terhadap variabel dependen. Jika $F_{\text {hitung }} \leq F_{\text {tabel, }}$ maka $H_{0}$ ditolak. Dan jika $F_{\text {hitung }} \geq F_{\text {tabel, maka }}$ $\mathrm{H}_{0}$ diterima.

\section{HASIL DAN PEMBAHASAN}

\section{Hasil}

\section{Uji Asumsi Klasik}

Uji asumsi klasik dilakukan untuk mendeteksi apakah model yang dikembangkan memiliki beberapa pengganggu atau tidak (Gujarati, 1995). Apabila model yang dikembangkan memiliki beberapa pengganggu seperti heteroskedasitas, auto kerelasi atau multikolinieritas, maka model yang dikembangkan tidak dapat digunakan. Dari hasil uji asumsi klasik dalam penelitian ini, dihasilkan bahwa ,model yang dihasilkan telah memenuhi uji asumsi klasik yang meliputi uju heterokedastisitas, uji multikolinearitas, uji autokorelasi dan uji normalitas.

\section{Hasil Analisis Korelasi}

Berdasarkan hasil perhitungan, menunjukkan bahwa besarnya nilai korelasi antara variabel independen (Price Earning Ratio, Price to Book Value, Debt Equity Ratio, Total Asset Turnover, Return on Investment, Return on Equity, Operating Profit Margin, dan Net Profit Margin) terhadap variabel dependen (Stock's Closing Price) masing-masing sebesar $(0,313 ; 0,420 ; 0,015 ; 0,120 ; 0,413 ; 0,308 ; 0,561$; dan 0,368). Berdasarkan hasil perhitungan di atas terlihat bahwa Operating Profit 
Margin memiliki koefisien korelasi yang paling besar jika dibandingkan dengan Price Earning Ratio, Price to Book Value, Debt Equity Ratio, Total Asset Turnover, Return on Investment, Return on Equity, dan Net Profit Margin. Hal ini menunjukkan hubungan antara Operating Profit Margin dengan Stock's Closing Price memiliki keterkaitan lebih erat jika dibandingkan dengan Price Earning Ratio, Price to Book Value, Debt Equity Ratio, Total Asset Turnover, Return on Investment, Return on Equity, dan Net Profit Margin.

Berdasarkan tabel di atas dapat dijelaskan bahwa variabel Price Earning Ratio, Price to Book Value, Debt Equity Ratio, Total Asset Turnover, Return on Investment, Return on Equity, Operating Profit Margin, dan Net Profit Margin memiliki hubungan dengan harga saham pada saat penutupan (closing price). Pola hubungan yang ditunjukkan adalah positif dan signifikan pada derajat keyakinan 99\% terhadap harga saham pada saat penutupan (closing price).

\section{Hasil Analisis Regresi Berganda}

Berdasarkan hasil pengujian dengan analisis regresi untuk masingmasing variabel fundamental dapat dijelaskan sebagai berikut:

Tabel 2

Rekapitulasi Regresi Terhadap Harga Saham

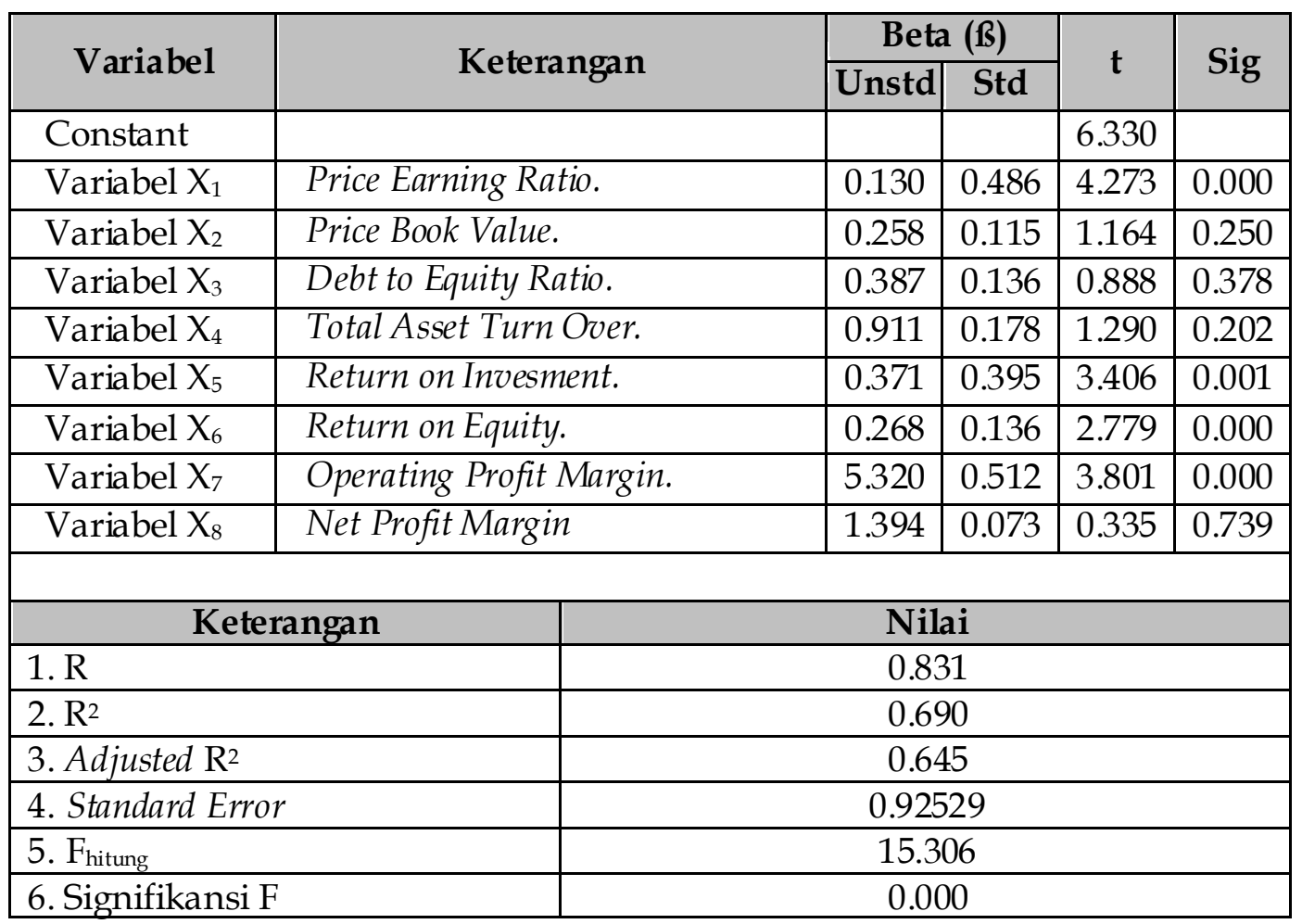

Sumber: Data Diolah 
Nilai R menunjukkan kemampuan model untuk menjelaskan fenomena (koefisien korelasi) yang diamati. Dari analisis ditemukan Nilai R sebesar 0,831 atau $83,1 \%$, artinya variabel $X_{1}$ sampai dengan $X_{8}$ mempunayi hubungan sangat kuat terhadap Y. Nilai R2 (koefisien determinasi) diperoleh sebesar 0,690 atau 69,0\%, atau dapat dikatakan Price Earning Ratio, Price to Book Value, Debt Equity Ratio, Total Asset Turnover, Return on Investment, Return on Equity, Operating Profit Margin, dan Net Profit Margin secara serentak memiliki pengaruh yang signifikan terhadap harga saham. Artinya kemampuan model regresi dalam menjelaskan keragaman/varian $\mathrm{Y}$ adalah sebesar 69,0\%, sedangkan nilai adjusted $\mathrm{R}^{2}$ mempunyai fungsi yang sama dengan $\mathrm{R}^{2}$ akan tetapi hanya melibatkan variabel independen yang signifikan terhadap variabel dependen saja, dari hasil perhitungan nilai adjusted $\mathrm{R}^{2}$ sebesar 0,645 atau 64,5\%. Artinya kemampuan model regresi dalam menjelaskan keragaman/varian $\mathrm{Y}$ untuk variabel yang signifikan adalah sebesar $64,5 \%$.

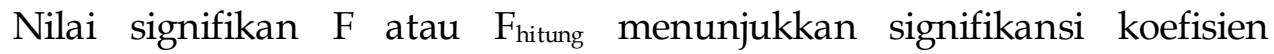
determinan atau membuktikan kecocokan model regresi, artinya persamaan regresi yang dihasilkan mampu menjelaskan variasi $\mathrm{Y}$. Pada tabel di atas $\mathrm{F}_{\text {hitung }}$ adalah 15.306 sedangkan $F_{\text {tabel }}$ untuk jumlah sampel $50(0.95,8,55)$ sebesar 2,11 sehingga $F_{\text {hit }}(15.306)$ lebih besar dari pada $F_{\text {tabel }}$ (2.11). Untuk sig $F$ adalah 0,000 dimana sig F lebih besar dari 0,05. Sehingga dapat disimpulkan bahwa model yang digunakan sesuai dengan model yang dikembangkan dan hasil analisis dapat digeneralisasikan pada populasi dengan derajat kesalahan $5 \%$ dan derajat keyakinan $95 \%$.

Berdasarkan rekapitulasi hasil analisis regresi berganda sebagaimana dapat dilihat dalam Tabel 5.4, pengaruh masing-masing variabel independen terhadap variabel dependen, arah hubungan dan tingkat signifikansinya dapat dijelaskan sebagai berikut:

Tabel 3

Model Regresi: Koefisien, Arah dan Signifikansi

\begin{tabular}{|ll|c|c|c|}
\hline \multicolumn{1}{|c|}{$\begin{array}{c}\text { Variabel } \\
\text { Bebas }\end{array}$} & $\begin{array}{c}\text { Koefisien } \\
\text { Regresi }\end{array}$ & $\begin{array}{c}\text { Tanda } \\
\text { Koefisien }\end{array}$ & Signifikansi \\
\hline $\mathrm{X}_{1}$ & Price Earning Ratio. & 0.486 & Positif & Signifikan \\
\hline $\mathrm{X}_{2}$ & Price Book Value. & 0.115 & Positif & Tidak Signifikan \\
\hline $\mathrm{X}_{3}$ & Debt to Equity Ratio. & 0.136 & Positif & Tidak Signifikan \\
\hline
\end{tabular}




\begin{tabular}{|ll|c|c|c|}
\hline $\mathrm{X}_{4}$ & Total Asset Turn Over. & 0.178 & Positif & Tidak Signifikan \\
\hline $\mathrm{X}_{5}$ & Return On Invesment. & 0.395 & Positif & Signifikan \\
\hline $\mathrm{X}_{6}$ & Return On Equity. & 0.136 & Positif & Signifikan \\
\hline $\mathrm{X}_{7}$ & Operating Profit Margin. & 0.512 & Positif & Signifikan \\
\hline $\mathrm{X}_{8}$ & Net Profit Margin & 0.073 & Positif & Tidak Signifikan \\
\hline
\end{tabular}

Sumber: Data Diolah

\section{Pembahasan}

Penelitian ini merupakan penelitian eksplanatori (explanatory research) yang mencoba untuk mencari keterkaitan antara beberapa variabel analisis fundamaental terhadap harga saham perusahaan sektor pertambangan yang terdaftar di Bursa Efek Indonesia. Pembahasan secara statistik mengenai keterkaitan masing-masing variabel yang digunakan dalam penelitian dapat dijelaskan sebagai berikut:

1. Pengaruh Price Earning Ratio (PER) terhadap Harga Saham.

Price Earning Ratio (PER) mengindikasikan perbandingan antara harga saham dibagi dengan Earning per Share (EPS). Semakin tinggi nilai PER, menunjukkan bahwa penilaian investor atas saham perusahaan juga semakin tinggi. Berdasarkan hasil pengujian statistik menunjukkan bahwa Price Earning Ratio (PER) memiliki arah hubungan positif terhadap harga saham dan berpengaruh signifikan terhadap harga saham sebesar 0,486. Sedangkan hasil uji statistik dengan menggunakan uji $t$, menunjukkan bahwa nilai $t_{\text {hitung }}$ dari variabel Price Earning Ratio (PER) sebesar 4,273; yang dimana nilai tersebut lebih besar dari pada nilai $t_{\text {tabel }}(0.95 ; 64)$ sebesar 1.67. Berdasarkan hasil pengujian di atas dapat disimpulkan bahwa variabel Price Earning Ratio (PER) memiliki pengaruh positif dan signifikan terhadap harga saham. Koefisien regresi diindikasikan oleh nilai Beta $(\beta)$, semakin tinggi nilai Beta ( $\beta$ ) menunjukkan semakin besar pengaruh variabel Price Earning Ratio (PER) terhadap harga saham.

2. Pengaruh Price to Book Value (PBV) terhadap Harga Saham

Price to Book Value (PBV) mengindikasikan perbandingan antara harga saham dibagi dengan Book Value (BV) dari nilai ekuitas. Book value diperoleh dari harga saham pada saat diterbitkan atau pada saat terjadi peristiwa terkait dengan perubahan ekuitas perusahaan seperti split stock, atau dapat juga terjadi karena perusahaan mengkonversi hutang menjadi saham baru, 
sehingga berpengaruh terhadap posisi ekuitas perusahaan. Semakin tingi nilai PBV, menunjukkan bahwa penilaian investor atas saham perusahaan juga semakin tinggi. Berdasarkan hasil pengujian statistik menunjukkan bahwa Price to Book Value (PBV) memiliki arah hubungan positif terhadap harga saham sedangkan pengaruh Price to Book Value (PBV) tidak signifikan terhadap harga saham sebesar 0,115 yang didukung dengan hasil uji statistik dengan menggunakan uji $t$, menunjukkan bahwa nilai $t_{\text {hitung }}$ dari variabel Price to Book Value (PBV) sebesar 1,164 yang dimana nilai tersebut lebih kecil dari pada nilai $t_{\text {tabel }}(0.95 ; 64)$ sebesar 1,67 . Berdasarkan hasil pengujian di atas dapat disimpulkan bahwa variabel Price to Book Value (PBV) memiliki pengaruh positif akan tetapi tidak signifikan terhadap harga saham. Koefisien regresi diindikasikan oleh nilai Beta $(\beta)$, semakin tinggi nilai Beta ( $\beta$ ) menunjukkan semakin besar pengaruh variabel Price to Book Value (PBV) terhadap Harga Saham.

3. Pengaruh Debt to Equity Ratio (DER) terhadap Harga Saham

Debt to Equity Ratio (DER) mengindikasikan perbandingan antara total kewajiban jangka panjang perusahaan dibagi dengan Total Equity. Semakin tingi nilai DER, menunjukkan bahwa posisi hutang jangka panjang perusahaan juga semakin tinggi jika dibandingkan dengan ekuitas perusahaan. Berdasarkan hasil pengujian statistik menunjukkan bahwa Debt to Equity Ratio (DER) memiliki arah hubungan positif terhadap harga saham dan berpengaruh tidak signifikan terhadap harga saham sebesar 0,136 yang dibuktikan dengan hasil uji statistik dengan menggunakan uji $t$, dengan hasil nilai $t_{\text {hitung }}$ dari variabel Debt to Equity Ratio (DER) sebesar 0,888 dimana nilai tersebut lebih kecil dari pada nilai $t_{\text {tabel }}(0.95 ; 64)$ sebesar 1,67 Berdasarkan hasil pengujian di atas dapat disimpulkan bahwa variabel Debt to Equity Ratio (DER) memiliki pengaruh positif akan tetapi tidak signifikan terhadap harga saham. Koefisien regresi diindikasikan oleh nilai Beta $(\beta)$, semakin tinggi nilai Beta $(\beta)$ menunjukkan semakin besar pula pengaruh variabel Debt to Equity Ratio (DER) terhadap Harga Saham.

4. Pengaruh Total Asset Turnover (TAT) terhadap Harga Saham

Total Asset Turnover (TAT) mengindikasikan perbandingan antara penjualan (Sales) dibagi dengan Total Asset (TA). Semakin tingi nilai Total Asset Turnover 
(TAT), menunjukkan bahwa tingkat perputaran asset perusahaan juga semakin tinggi. Rasio ini masuk ke dalam rasio aktivitas yang mengindikasikan kemampuan perusahaan untuk melakukan penjualan dari aset yang dimiliki, dengan kata lain menunjukkan efektivitas penggunaan seluruh harta yang dimiliki. Berdasarkan hasil pengujian statistik menunjukkan bahwa Total Asset Turnover (TAT) memiliki arah hubungan positif terhadap harga saham sedangkan pengaruh Total Asset Turnover (TAT) tidak signifikan terhadap harga saham sebesar 0.178. yang didukung dengan hasil uji statistik dengan menggunakan uji $t$, menunjukkan bahwa nilai $t$ hitung dari variabel Total Asset Turnover (TAT) sebesar 1,290 yang dimana nilai tersebut lebih kecil dari pada nilai $t$ tabel $(0.95 ; 64)$ sebesar 1,67. Berdasarkan hasil pengujian di atas dapat disimpulkan bahwa variabel Total Asset Turnover (TAT) memiliki pengaruh positif akan tetapi tidak signifikan terhadap harga saham. Koefisien regresi diindikasikan oleh nilai Beta $(\beta)$, semakin tinggi nilai Beta $(\beta)$ menunjukkan semakin besar pula pengaruh variabel Total Asset Turnover (TATO) terhadap Harga Saham.

5. Pengaruh Return on Investment (ROI) terhadap Harga Saham

Return on Investment (ROI) mengindikasikan perbandingan antara laba bersih dibagi dengan Total Investment yang diindikasikan oleh Total Asset (TA). Semakin tingi nilai ROI, menunjukkan bahwa tingkat keuntungan perusahaan dari asset yang digunakan semakin tinggi. Rasio ini masuk dalam kelompok rasio profitabilitas, dimana rasio ini mengindikasikan kemampuan perusahaan dalam menghasilkan laba dari aset yang dimiliki. Berdasarkan hasil pengujian statistik menunjukkan bahwa Return on Investment (ROI) memiliki arah hubungan positif terhadap harga saham dan berpengaruh signifikan terhadap harga saham sebesar 0.395. Sedangkan hasil uji statistik dengan menggunakan uji $t$, menunjukkan bahwa nilai $t_{\text {hitung }}$ dari variabel Return on Investment (ROI) sebesar 3.406, yang dimana nilai tersebut lebih besar dari pada nilai $t_{\text {tabel }}(0.95 ; 64)$ sebesar 1,67 . Berdasarkan hasil pengujian di atas dapat disimpulkan bahwa variabel Return on Investment (ROI) memiliki pengaruh positif dan signifikan terhadap harga saham. Koefisien regresi diindikasikan oleh nilai Beta $(\beta)$, semakin tinggi nilai Beta 
( $\beta$ ) menunjukkan semakin besar pula pengaruh variabel Return on Investment (ROI) terhadap Harga Saham.

6. Pengaruh Return on Equity (ROE) terhadap Harga Saham

Return on Equity (ROE) mengindikasikan perbandingan antara laba bersih dibagi dengan ekuitas (equity). Semakin tingi nilai ROE, menunjukkan bahwa tingkat keuntungan perusahaan dari ekuitas yang digunakan semakin tinggi. Rasio ini masuk dalam kelompok rasio profitabilitas, dimana rasio ini mengindikasikan kemampuan perusahaan dalam menghasilkan laba dari aekuitas yang dimiliki. Berdasarkan hasil pengujian statistik menunjukkan bahwa Return on Equity (ROE) memiliki arah hubungan positif terhadap harga saham dan berpengaruh signifikan terhadap harga saham sebesar 0,136 . Hasil uji statistik dengan menggunakan uji $t$, menunjukkan bahwa nilai

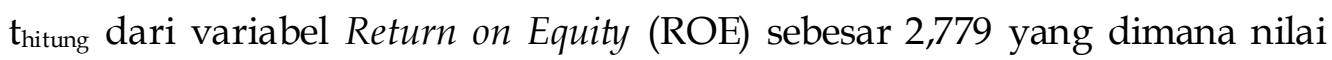
tersebut lebih besar dari pada nilai t tabel $(0.95 ; 64)$ sebesar 1.67. Berdasarkan hasil pengujian di atas dapat disimpulkan bahwa variabel Return on Equity (ROE) memiliki pengaruh positif dan signifikan terhadap harga saham. Koefisien regresi diindikasikan oleh nilai Beta $(\beta)$, semakin tinggi nilai Beta ( $\beta$ ) menunjukkan semakin besar pengaruh variabel Return on Equity (ROE) terhadap Harga Saham.

7. Pengaruh Operating Profit Margin (OPM) terhadap Harga Saham Operating Profit Margin (OPM) mengindikasikan perbandingan antara laba operasi dibagi dengan penjulan bersih (net sales). Semakin tingi nilai OPM, menunjukkan bahwa prosentase perolehan laba operasi dari penjualan juga semakin tinggi. Rasio ini termasuk dalam rasio profitabilitas yang mengindikasikan kemampuan perusahaan untuk memperoleh laba operasi dari aktivitas penjualan yang dilakukan. Berdasarkan hasil pengujian statistik menunjukkan bahwa Operating Profit Margin (OPM) memiliki arah hubungan positif terhadap harga saham dan berpengaruh signifikan terhadap harga saham sebesar 0,512. Sedangkan hasil uji statistik dengan menggunakan uji $t$, menunjukkan bahwa nilai $t_{\text {hitung }}$ dari variabel Operating Profit Margin (OPM) sebesar 3,801 yang dimana nilai tersebut lebih besar dari pada nilai $t_{\text {tabel }}$ $(0.95 ; 64)$ sebesar 1,67. Berdasarkan hasil pengujian di atas dapat disimpulkan bahwa variabel Operating Profit Margin (OPM) memiliki pengaruh positif dan 
signifikan terhadap harga saham. Koefisien regresi diindikasikan oleh nilai Beta $(\beta)$, semakin tinggi nilai Beta $(\beta)$ menunjukkan semakin besar pula pengaruh variabel Operating Profit Margin (OPM) terhadap Harga Saham.

8. Pengaruh Net Profit Margin (NPM) terhadap Harga Saham

Net Profit Margin (NPM) mengindikasikan perbandingan antara laba bersih dibagi dengan penjulan bersih (net sales). Semakin tingi nilai NPM, menunjukkan bahwa prosentase perolehan laba bersih dari penjualan juga semakin tinggi. Semakin tinggi net profit margin semakin baik operasi perusahaan (Syamsuddin, 2000). Rasio ini termasuk dalam rasio profitabilitas yang mengindikasikan kemampuan perusahaan untuk memperoleh laba bersih dari aktivitas penjualan yang dilakukan. Berdasarkan hasil pengujian statistik menunjukkan bahwa Net Profit Margin (NPM) memiliki arah hubungan positif terhadap harga saham sedangkan pengaruh Net Profit Margin (NPM) tidak signifikan terhadap harga saham sebesar 0.073 yang didukung dengan hasil uji statistik dengan menggunakan uji t, menunjukkan bahwa nilai $t_{\text {hitung }}$ dari variabel Net Profit Margin (NPM) sebesar 0,335 yang dimana nilai tersebut lebih kecil dari pada nilai $t_{\text {tabel }}(0.95 ; 64)$ sebesar 1,67. Berdasarkan hasil pengujian di atas dapat disimpulkan bahwa variabel Net Profit Margin (NPM) memiliki pengaruh positif akan tetapi tidak signifikan terhadap harga saham. Koefisien regresi diindikasikan oleh nilai Beta $(\beta)$, semakin tinggi nilai Beta $(\beta)$ menunjukkan semakin besar pula pengaruh variabel Net Profit Margin (NPM) terhadap Harga Saham.

\section{KESIMPULAN}

Berdasarkan hasil analisis dan pembahasan yang menguji pengaruh dan keterkaitan variabel fundamental terhadap harga saham perusahaan sektor pertambangan yang terdaftar di Bursa Efek Indonesia dapat ditarik beberapa kesimpulan sebagai berikut:

1. Analisis fundemental menyatakan bahwa harga saham dapat diprediksi berdasarkan kinerja keuangan internal perusahaan, sedangkan analisis teknikal lebih menekankan pada kecenderungan (tren) harga saham di masa lalu. 
2. Hasil nilai $F$ sebesar 15,306 sedangkan nilai $F_{\text {tabel }}$ untuk jumlah sampel sebanyak $50(0.95,8 ; 55)$ sebesar $(2.11)$, sehingga nilai $\mathrm{F}_{\text {hitung }}$ lebih besar dari $\mathrm{F}_{\text {tabel. }}$ Berdasarkan hasil perhitungan di atas dapat dibuktikan bahwa variabel Price Earning Ratio, Price to Book Value, Debt Equity Ratio, Total Asset Turnover, Return on Investment, Return on Equity, Operating Profit Margin, dan Net Profit Margin secara bersama-sama (simultan) memiliki pengaruh signifikan terhadap harga saham.

3. Hasil nilai t untuk variabel Price Earning Ratio, Price to Book Value, Debt Equity Ratio, Total Asset Turnover, Return on Investment, Return on Equity, Operating Profit Margin, dan Net Profit Margin sebesar 4,273; 1,164; 0,888; 1,290; 3,406; 4,$779 ; 3,801$; dan 0,335 sedangkan nilai $t_{\text {tabel }}$ untuk jumlah sampel sebanyak 50 $(0.95,50)$ sebesar $(1,670)$, sehingga nilai $t_{\text {hitung }}$ lebih besar dari $t_{\text {tabel. }}$. Berdasarkan hasil perhitungan di atas dapat dibuktikan bahwa variabel Price Earning Ratio, Return on Investment, Return on Equity, dan Operating Profit Margin, secara parsial memiliki pengaruh positif dan signifikan terhadap harga saham.

4. Hipotesis 2 yang menyatakan bahwa diduga diantara faktor fundamental faktor Price Earning Ratio (PER) mempunyai pengaruh yang dominan terhadap perubahan harga saham pada perusahaan pertambangan yang go publik di Bursa Efek Indonesia (BEI), dibandingkan dengan faktor yang lain, dan mempunyai koefisien arah positif, secara statistik tidak dapat diterima.

\section{DAFTAR PUSTAKA}

Gujarati, Damodar. 1998. Ekonometrika Dasar, Cetakan ke 4. Jakarta: Penerbit Erlangga.

Husnan, Suad. 2001. Dasar-dasar Teori Portofolio dan Analisis Sekuritas, Edisi Ketiga Cetakan kedua. Yogyakarta: Penerbit UPP AMP YKPN.

Jogiyanto. 2000. Teori Portofolio dan Analisis Investasi, Edisi Kedua, Cetakan Pertama. Yogyakarta: BPFE.

Penman, S.H. 1992. Return to Fundamental. Journal of Accounting, Auditing and Finance 7. (fall): $465-483$. 
Sawir, Agnes. 2001. Analisis Kinerja Keuangan Perusahaan dan Perencanaan Keuangan Perusahaan. Jakarta: Gramedia.

Sjahrir. 1995. Analisis Bursa Efek, Cetakan II. Jakarta: PT. Gramedia Pustaka Umum.

Silalahi, Donalson. 1991. Beberapa Faktor yang Mempengaruhi Perubahan Harga Saham (Studi Pasar Modal Indonesia. Thesis. Program Pascasarjana Universitas Airlangga, Surabaya.

Subroto, Bambang. 1991. Akuntansi Keuangan Intermidiate, Edisi Kedua. Yogyakarta: Penerbit BPFE.

Weston, J Fred \& Copeland, E. Thomas. 1992. Manajemen Keuangan, Terjemahan, Cetakan ketujuh, Jilid I. Jakarta: Penerbit Erlangga.

Weston, J Fred \& Copeland, E. Thomas. 1997. Manajemen Keuangan, Terjemahan, Cetakan ketujuh, Jilid II. Jakarta: Penerbit Erlangga.

Sekaran, Uma. 1992. Research Methods For Business, Second Edition. New York; John Wiley and Son, Inc.

Sharp, William F. and Gordon J. Alexander. 1990. Investment, 4th Edition. USA. Prentice Hall.

Siamat, Dahlan. 1995. Manajemen Lembaga Keuangan, Jakarta: Intermedia.

Solimun. 2002. Multivariate Anaysis, SEM, Lisrel dan AMOS. Fakultas MIPA, Universitas Brawijaya, Malang. 